\title{
Sovereign Credit Ratings, Growth Volatility and the Global Financial Crisis
}

\author{
Gazi Mainul Hassan ${ }^{1}$ \\ gmhassan@waikato.ac.nz \\ Department of Economics, Waikato Management School, \\ University of Waikato, New Zealand \\ Eliza $\mathrm{Wu}$ \\ Eliza.Wu@uts.edu.au \\ Finance Discipline Group, University of Technology, Sydney \\ NSW, Australia
}

\begin{abstract}
:
Using monthly data from January 1996 to May 2010 for a panel of 76 developed and emerging economies and adopting an instrumental variable estimation technique by correcting for both heterogeneity and endogeneity with the generalised two-stage least squares (G2SLS, EC2SLS) procedure method suggested by Balestra and Varadharajan-Krishnakumar (1987) and Baltagi (1995), this paper provides empirical evidence that volatility of per capita GDP growth is reduced when there are positive changes in credit ratings; in other words when sovereign credit risk improves. To deal with potential simultaneity between sovereign credit ratings and output volatility, a system (3SLS) approach is undertaken, and our findings remain robust. By weakening the volatility dampening effects of ratings changes, it is found that the global financial crisis $(G F C)$ has enhanced macroeconomic volatility. One of the channels via which sovereign rating changes affect growth volatility is the financial markets' repricing of sovereign default risk that is reflected in sovereign credit default swap (CDS) spreads and its volatility.
\end{abstract}

Keywords: Growth volatility, sovereign credit ratings, financial globalisation, global financial crisis, monetary policy.

JEL Classification: C33, C36, E52.

\footnotetext{
${ }^{1}$ Corresponding author. Department of Economics, Waikato Management School, University of Waikato, Private Bag 3105, Hamilton, New Zealand. Email: gmhassan@waikato.ac.nz; Phone: +64 7 8585164; Fax: +64 78384331 . We thank an anonymous referee of this journal for providing helpful comments and also the members at the economics research division at the Reserve Bank of New Zealand.
} 


\section{Introduction}

Sovereign credit ratings issued by international credit rating agencies (CRAs) are one of the key variables affecting sovereign nations' access to international credit markets (Ratha et al., 2007, 2010). Sovereign credit ratings thus affect not only the process of obtaining funds from the loan market and the direction of international banking flows as identified in Kim and $\mathrm{Wu}$ (2011) but can also be effective in determining the flow of foreign direct investments and portfolio equity flows (Kim and $\mathrm{Wu}, 2008)$. As the access to international financing is crucial for funding aggregate investments and consumption, there should be direct effects from sovereign credit ratings activity on individual countries' economic growth.

The contribution of this paper is to show that changes in the sovereign credit ratings of countries can convey useful information to creditors and investors in the international market and have consequences on the real economy. We empirically examine the effect of Standard and Poors' (S\&P) sovereign credit ratings and re-ratings on the volatility of output growth using monthly data over the period from 1996 to 2010 for a global sample of 76 countries. ${ }^{2}$ We hypothesise that a country with a higher credit rating is better able to access international capital markets because a high sovereign credit rating (and/or a rating upgrade) can lower the cost of borrowing and thereby smooth consumption and investment patterns and consequently reduce the volatility in output growth. To identify the channel via which sovereign rating changes affect output volatility, we also test the effect of credit ratings and changes in credit ratings on the market pricing of perceived sovereign default risk reflected in sovereign credit default swap (CDS) spreads. Supporting this hypothesis, Ozatay et al. (2009) illustrate that sovereign spreads

\footnotetext{
${ }^{2}$ We focus only on foreign currency sovereign ratings assessments provided by S\&P as previous studies have found that $\mathrm{S} \& \mathrm{P}$ rating changes exert the greatest impact on stock market returns and are less anticipated (see, e.g., Reisen and von Maltzan (1999), Brooks et al. (2004)).
} 
depend on domestic fundamentals proxied by sovereign credit ratings. Furthermore, the paper also tests whether the Global Financial Crisis (GFC) increased output volatility by weakening the significant relationship between sovereign credit ratings and output volatility.

The link between output volatility and economic growth is well-established. Ramey and Ramey (1995) reveal in their seminal paper that countries with a higher volatility of output also have a lower growth rate of output. This result remains unchanged even after controlling for other country-specific variables which are found to be robust in the literature such as the investment to GDP ratio.Given that high economic growth is what governments want to achieve, one of the key objectives of macroeconomic policies should also be targeted to reduce output volatility. Therefore, it is important to understand what determines output volatility and we contribute new evidence on the importance of sovereign credit rating assessments towards this goal.

In the literature, Easterly, Islam and Stiglitz (2000) provide some insights into the empirical determinants of output volatility. They show that the development of the domestic financial sector plays a crucial role in lowering output volatility and that this relationship is non-linear. Prasad et al. (2004) demonstrate that increases in financial globalization measured in terms of cross border capital inflow and capital account liberalisation has, on average reduced output and consumption volatility in industrial economies and the "less financially integrated" developing economies. Therefore, enhanced access to foreign capital markets from improvements in sovereign credit assessments is likely to be an important factor determining output growth volatility. However to date, there has been a dearth of attention on the real economic effects of revisions in sovereign credit ratings despite the spate of sovereign rating 
downgrades that have coincided with economic downturns in advanced economies in the postGFC era and we promptly address this void in this study.

The remainder of this paper is organised as follows. Section 2 reviews the extant sovereign ratings literature. Section 3 presents the most important stylised facts for output growth volatility and sovereign credit ratings. Section 4 provides the empirical model and analysis of the results. In particular, this section analyses the impact of sovereign credit ratings on a variety of volatility models where a counterfactual analysis is presented. Finally, section 5 provides concluding remarks and sketches the major policy implications that follow from this research.

\section{Literature Review}

It has been noted that "the recent financial market turbulence has brought credit rating agencies under fire" and academics as well as policy-makers are arguing for a reform of the business model of CRAs (Portes 2008). Rating agencies are faced with a serious conflict of interest, to the extent that their remuneration comes from rated issuers (Mathis, McAndrews and Rochet, 2009), both in the context of public or private borrowers. This is a crucial issue, given CRAs' considerable and increasing role in international capital markets. In this context, there is a large and useful literature studying the impact of sovereign credit ratings on market prices and bond spreads. Kaminsky and Schmukler (2001) find that downgrades and upgrades have an impact on country risk and stock returns: these rating changes are transmitted across countries, with neighbour-country effects being more significant.

The study of sovereign risk assessment has focused on comparing sovereign ratings to market spreads. For the period 1987-1994, Cantor and Packer (1996) find a greater impact on bond spreads from a rating change in the case of Moody's or if it is related to speculative-grade 
countries. Reisen and Von Maltzan (1999) show that sovereign ratings have asymmetric effects as in the period 1989-1997, Fitch, Moody's and S\&P's downgrades have a significant impact on bond spreads, contrary to upgrades, which were anticipated by the market. For them, sovereign ratings have the potential to moderate euphoria among investors on emerging markets but credit rating agencies failed to exploit that potential in the 1990s. Sy (2002) highlights the strong negative relationship between sovereign credit ratings and declines in EMBI+ spreads during periods of high risk aversion (e.g., 1997-1998). Mora (2006) examines Moody's and S\&P's ratings and concludes that the procyclicality of ratings is not ascertained when considering the post Asian financial crisis years. Analyzing sovereign ratings issued by the three rating agencies over 1993-2007, Gaillard (2009) finds that the procyclicality of ratings was much sharper during periods of high risk aversion (1997-1998 in particular) than periods of low risk aversion (2005-2007). In a different way, Cavallo et al. (2008) develop a simple Hausman specification test and find that there is some informational content in sovereign ratings that is not completely captured by market spreads. Additional tests reinforce their conclusion that sovereign ratings matter to financial market participants. Lastly, going beyond the traditional "ratings vs. spreads" view, Roubini and Manasse (2005) present an original sovereign risk assessment methodology by using a binary recursive tree. This enables them to better discuss appropriate policy options to prevent crises.

\section{Sovereign credit ratings, macroeconomic volatility and the stylized facts}

It can be seen from the survey of the literature in section 2 that the focus of the literature has been on analysing the effect of sovereign credit ratings on financial variables and not on macroeconomic variables. Sovereign credit ratings can have effects on macroeconomic volatility because higher credit ratings improve a country's creditworthiness which lowers the cost of borrowing in international capital markets. This allows countries to borrow in bad times, 
smooth consumption and reduce growth volatility. Sovereign credit ratings can also serve as a signal for the overall fiscal discipline of the economy, e.g., a country with an excessive government deficit will be assigned a lower sovereign credit rating and vice versa. A high sovereign rating can signal macroeconomic strength and this can work to boost both domestic and foreign investors' confidence thereby reducing output volatility.

The paper uses monthly data on sovereign credit ratings for foreign currency denominated debt provided by Standard and Poors for the period from January 1996 to May 2010 in 76 developed and emerging economies. In Figure 1 the graphs of sovereign credit ratings, the changes in sovereign ratings and growth volatility are combined together. The data shown are average values for all the countries in the sample. The first panel in Figure 1 shows the dynamics of sovereign credit ratings from 1996 to 2010 . The red line indicates the time since the onset of the global financial crisis (GFC). It can be seen that average monthly ratings have gone up throughout the late 90s and early 00s and have remained more or less constant from the early months of 2000 until 2003. There seems to be a gradual decline of sovereign credit ratings from late 2003 until 2006 when it starts rising again but only up to 2007 when GFC sets in coupled with a persistent decline in average ratings. 


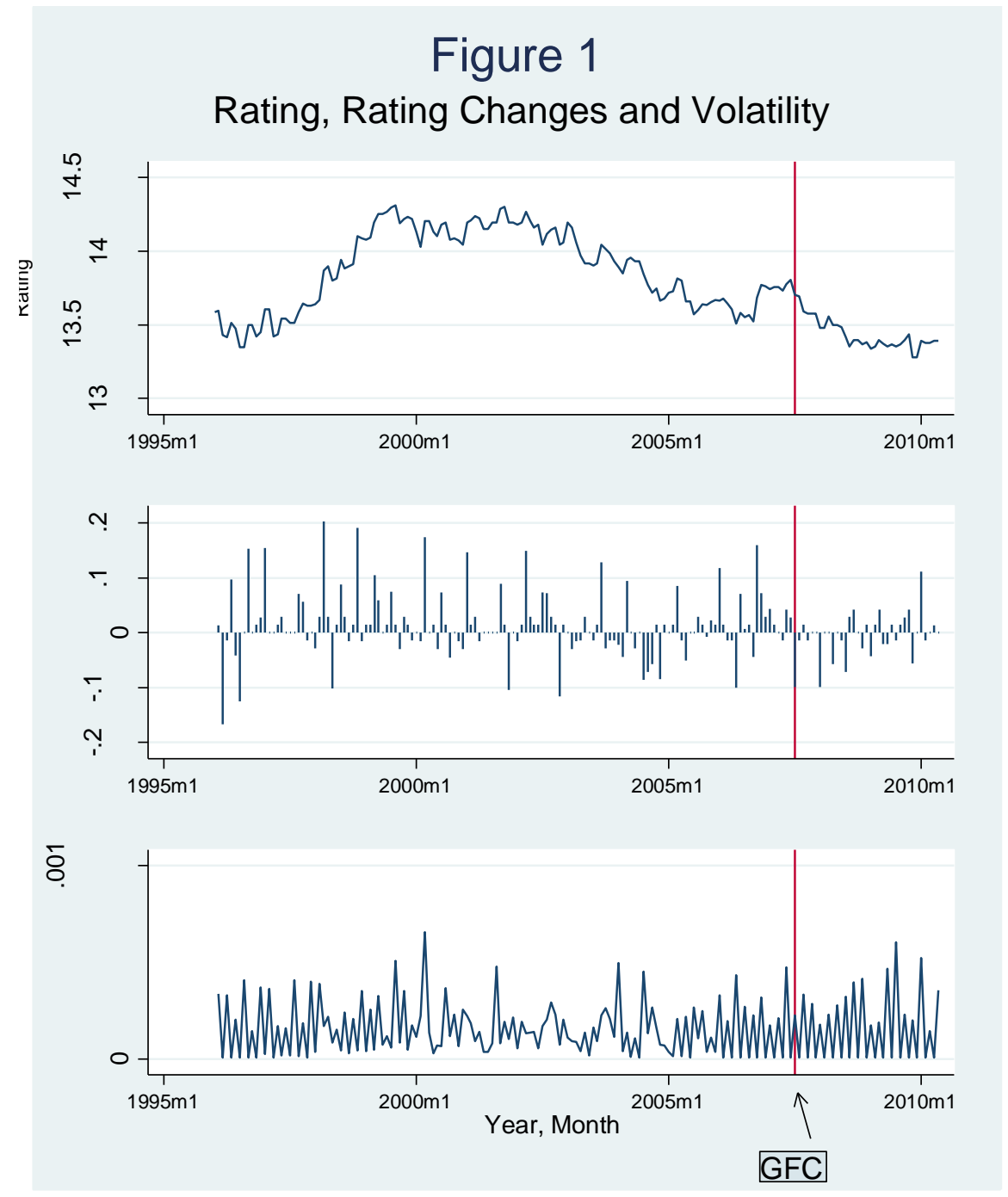

The second panel in Figure 1 shows the average changes in sovereign credit rating for the sample period. It can be seen that in the period prior to 2004, the frequency of positive rating changes was high compared with the period from 2004 to 2010 . In the latter period the frequency of negative ratings is much higher.

The third panel of Figure 1 shows the dynamics of growth volatility for the same time period. There seems to be three distinct phases. The early months of 1996 to 2000 is a period of high volatility followed by a relatively tranquil period from 2001 to 2004 where growth volatility has been much lower. From 2005 onward another high volatility period sets in throughout the GFC and increases later in the year 2010. 
These figures suggest that there may be a possible link between sovereign credit ratings and output volatility. Before investigating in an econometric model, we first combine the sovereign ratings and/or its changes together with output volatility in separate graphs. This is done in Figures 2 and 3 respectively. In Figure 2, the inverse relationship between sovereign credit quality and growth volatility appears to be stronger post-GFC.

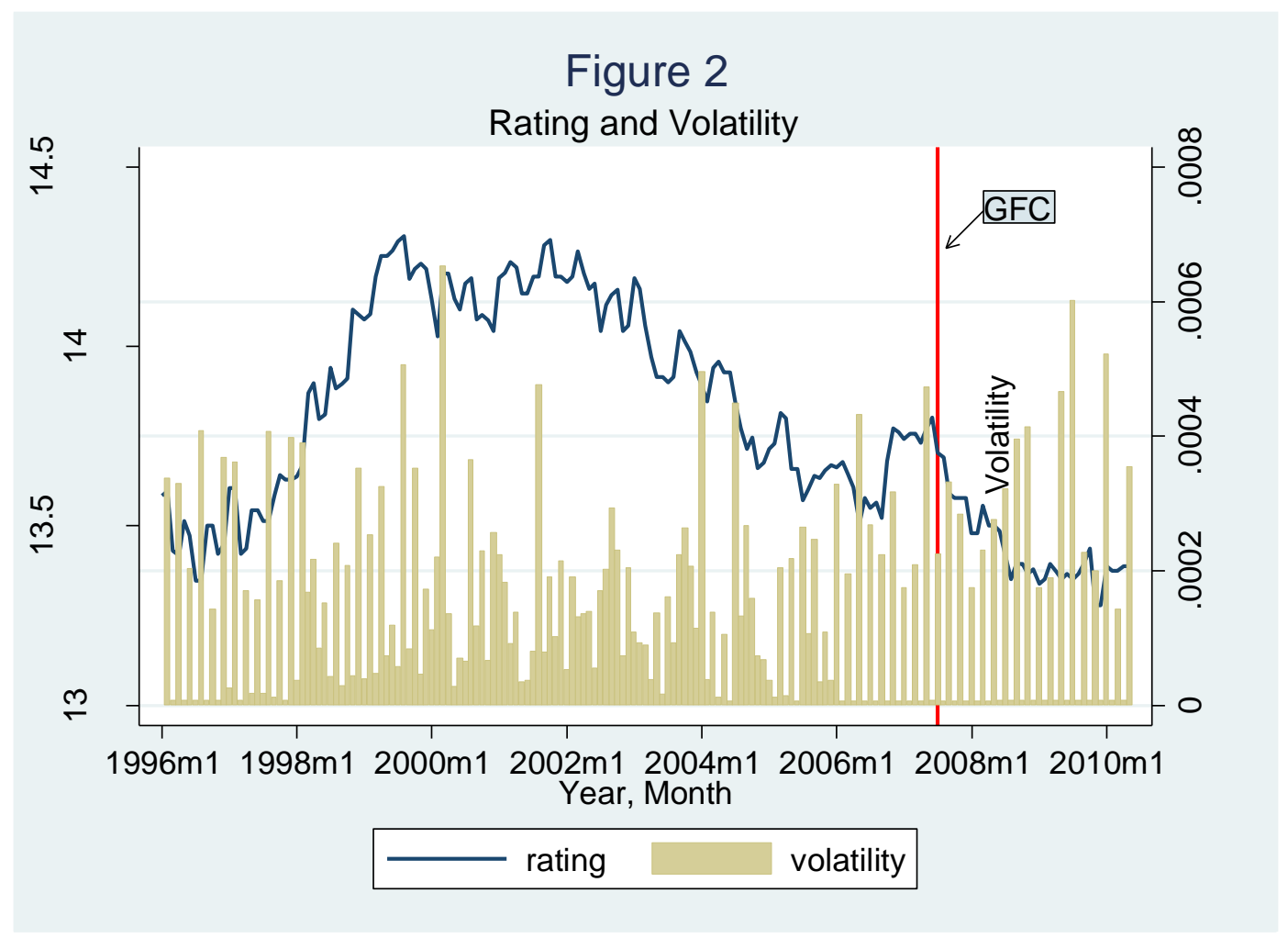

Figure 3 provides a similar analysis between output volatility and changes in sovereign ratings. High positive changes in sovereign credit ratings and low negative changes in sovereign rating are associated with higher growth volatility. From January 1996 to January 2000 - a period of high growth volatility - the frequency of large positive changes in sovereign credit quality is prominent. Similarly, from January 2005 to May 2010 - another period of high growth volatility - the frequency of negative although low, changes in sovereign ratings is more prominent. 


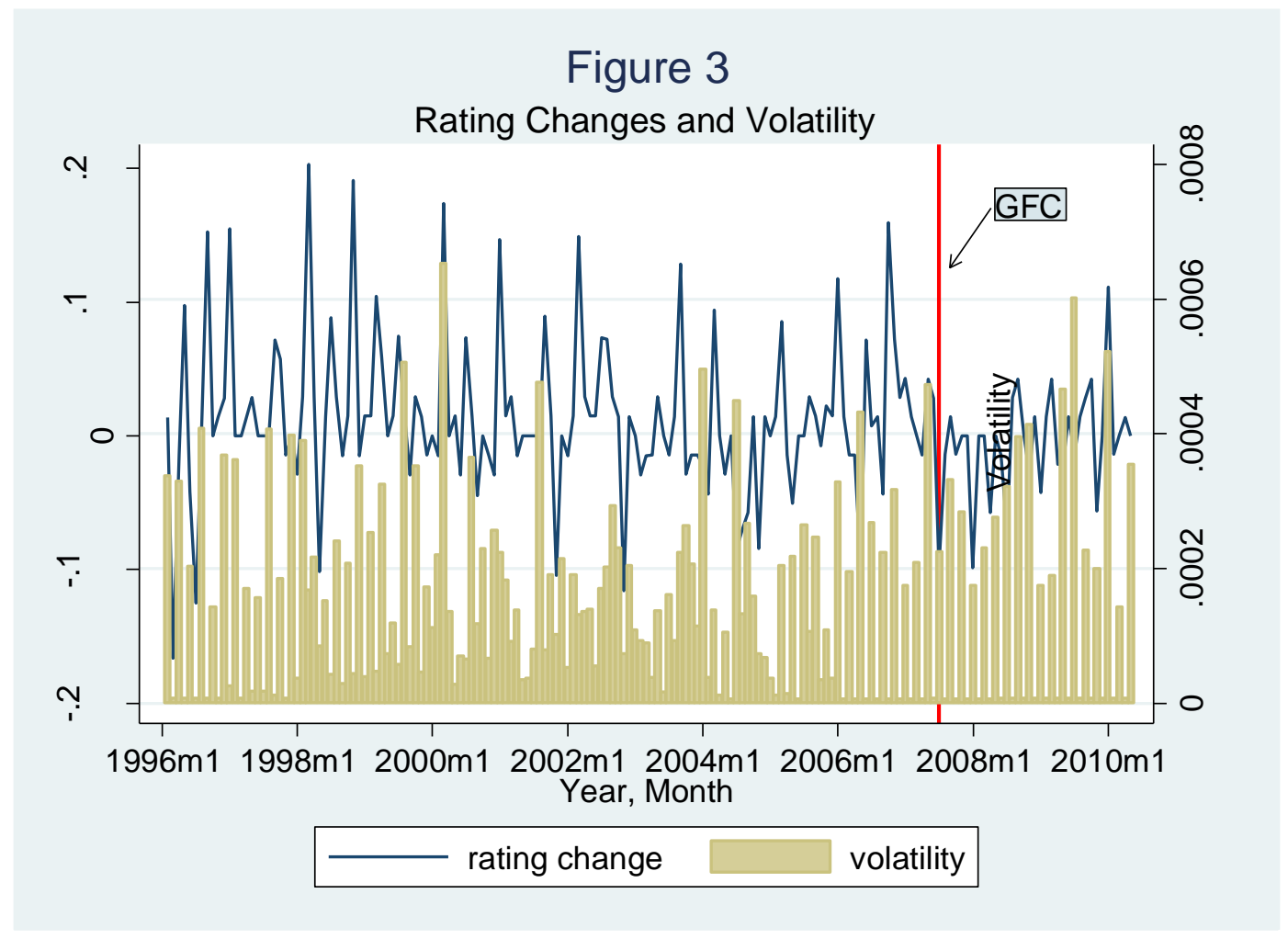

Based on the graphical analysis of the data provided, it is possible to conclude that sovereign credit quality and growth volatility could be related as argued in the beginning of this section. The next section will present results based on a formal econometric model to test for a link between sovereign credit ratings and growth volatility and if this relationship is robust.

\section{Econometric Model and Analysis of Results}

To facilitate understanding the link between sovereign ratings and output volatility, this section will undertake an empirical analysis of the key variables. The specification that will be estimated is as follows:

$$
\begin{aligned}
& V O L_{i t}=\beta_{0}+\beta_{1} R A T I N G_{i t}+\beta_{2} D_{R A T I N G}+\beta_{3} G F C_{t}+ \\
& \beta_{4}(G F C \times D R A T I N G)_{i t}+\beta_{6} X_{i t}+u_{i t}
\end{aligned}
$$


Where $V O L_{i t}$ is the volatility of the growth of per capita real GDP for country $i$ which is computed as deviation of actual growth rate from the trend following the methodology in Rao and Hassan (2012) and $\mathrm{u}_{\mathrm{it}}$ is the error term. RATING ${ }_{i t}$ is a linearly transformed series of sovereign credit ratings over time, $D R A T I N G_{i t}$ are the changes in sovereign credit ratings, $G F C$ (Global Financial Crisis) is an indicator variable that takes the value of 1 between July, 2007 to May 2010, and zero otherwise, $X_{i t}$ is a matrix of control variables which includes the price of oil $(O I L)$ and (STOCK) which is the measure of the total value of shares traded during the month (current US\$). It is commonly used as a proxy for financial market trading activity and stock liquidity and more broadly for financial development. It has been shown in the extant literature to be important for explaining global growth opportunities (see for example, Bekaert et al., 2007).

To explain output volatility we control for the world oil price and financial development as measured by the value of stock trading in the country concerned. First, oil is recognised as a critical energy input into production and that world oil prices are barometers of global economic conditions (Darby, 1982). Furthermore, there is a well-developed literature establishing the clear link between financial development and economic growth (see for example, Levine and Zervos, 1998).

The expected signs of the estimated coefficients are as follows. Firstly, since it is expected that sovereign credit ratings and their changes are expected to reduce growth volatility, the expected signs of $\beta_{1}$ and $\beta_{2}$ are negative. However, the coefficient of change in sovereign credit rating $(D R A T I N G)$, i.e. $\beta_{2}$ is more important and meaningful than the coefficient of RATING, i.e. $\beta_{1}$. The reason is that the volatility of $G D P$ should be more reactive to changes in the informational 
content of the economy which is more appropriately conveyed by ratings changes. Secondly, because the $G F C$ has created greater economic uncertainty and financial instability, the expected sign of $\beta_{3}$ is positive. Thirdly, the expected sign of $\beta_{4}$ which is the coefficient of the interacting term is a priori ambiguous. A positive coefficient will imply the $G F C$ has strengthened the sovereign rating - volatility relationship, and a negative coefficient will imply that it has weakened it. With regard to the control variables, it is expected that a higher oil price and an increase in the number of stocks traded will increase growth volatility and hence the signs of their estimated coefficients would be positive.

The results of the estimation of equation (1) using a fixed effect within transformation estimator are presented in Table 1. At first the equation is estimated without any interaction terms and control variables, and subsequently the control variables are added. The estimated results without and with the control variables are in columns (1) and (2) respectively. It can be seen in column (1) that the sign of RATING is negative and significant. It can also be seen that the coefficient of DRATING is negative and significant at the 1 percent significance level. Both of these estimations show that sovereign credit ratings are negatively associated with growth volatility. The estimated coefficient of the $G F C$, an indicator variable, is positive as expected, but it is not significant. The robustness of these results depends on the addition of the interaction term and the control variables to the regression equation. This is done in column (2). It can be seen that the estimated coefficient of RATING remains negative and is also significant at the 1 percent level while there is only a very marginal increase of the magnitude in the estimated coefficient of DRATING but it is still negative and significant at the 1 percent level. Based on the current model, it can be concluded that higher sovereign credit ratings is associated with lower growth volatility in this sample. The coefficient of $G F C$ is almost similar to its previous value and it is still positive but insignificant. This does not give sufficient ground 
to conclude that the GFC heightened growth volatility. Interestingly, the coefficient of the interaction term turns out to be negative though insignificant at all conventional significance levels $(\mathrm{p}$-value $=0.101)$

\section{Table 1}

Dependent variable: Volatility of per capita GDP growth (Fixed Effect Within Transformation Estimator)

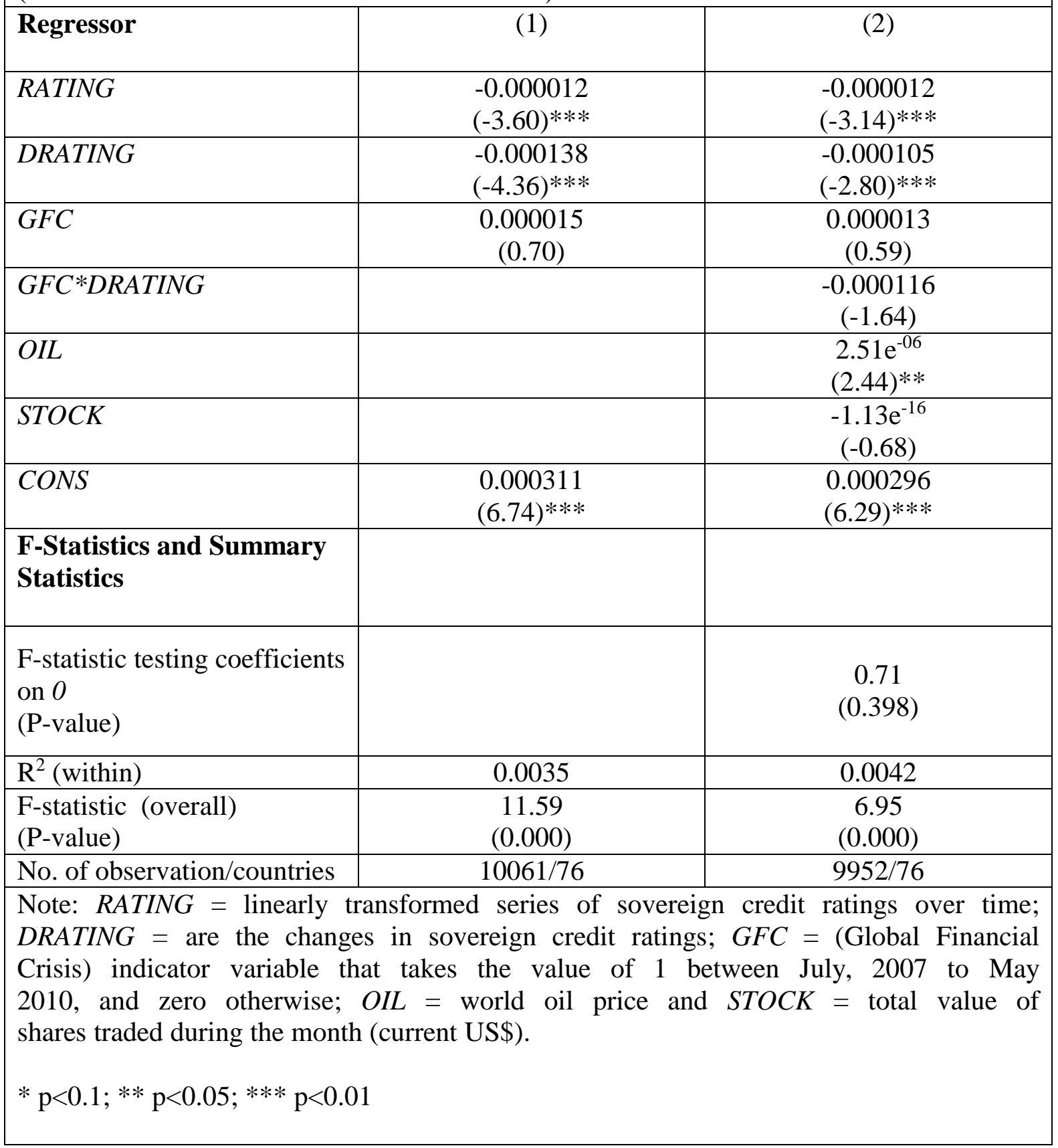


The test of the joint significance of the DRATING variables turns out to be insignificant. Hence no conclusion can be made on whether the $G F C$ has contributed to growth volatility by interacting with credit ratings or not. Among the control variables it is found that world oil price is also a contributor to growth volatility because the estimated coefficient of the $O I L$ variable is positive and significant. The same cannot be concluded for the other control variable, because $S T O C K$ is insignificant.

The results in Table 1 which are analysed above will have to be taken with some degree of caution. The estimated coefficients for the sovereign rating variables may be biased because the variable RATING could be endogenous and correlated with the error term. Moreover, because the 76 countries in the sample are chosen from different regions around the world, there is a possibility that the variance of the error term exhibits some form of heteroscedasticity. These two problems need to be addressed in order to have some meaningful results. Therefore to account for endogeneity equation (1) is estimated using an instrumental variable (IV) estimator using the following framework:

$$
\begin{aligned}
& V O L_{i t}=\beta_{0}+\beta_{1} R A T I N G_{i t}+\beta_{2} D R A T I N G_{i t}+\beta_{3} G F C_{t}+ \\
& \beta_{4}(G F C \times D R A T I N G)_{i t}+\beta_{6} X_{i t}+u_{i t} \\
& R A T I N G_{i t}=\gamma_{1} I V_{i t}+v_{i t} \\
& E\left(R A T I N G_{i t} * u_{i t}\right) \neq 0 \text { but } E\left(I V_{i t} * v_{i t}\right)=0
\end{aligned}
$$

The results of the IV estimation of equation (2) are presented in Table 2. The first column presents the fixed effect-IV results (within transformation) correcting for endogeneity but assuming standard properties for the error term. To ensure that number of not included instruments exceeds the number of possibly endogenous variable RATING, we included two non-included instruments to test whether or not the not included instruments are exogenous. 
The instruments include a composite risk measure (COMPRISK) sourced from the International Country Risk Guide (ICRG) as it incorporates aspects of financial, economic and political risks within countries and a realised equity market return (RRET) measure which we computed from S\&P500 index for each country in the sample. The results are qualitatively similar to those found in the simple fixed-effect estimation in Table 1. Both the coefficients RATING and DRATING are negative and significant at 5 percent level, implying that the volatility reducing effect of sovereign credit ratings is present. The $G F C$ indicator variable remains insignificant as before, however the estimated coefficient of the interaction between the GFC and DRATING is negative and significant at the conventional 5 percent level. Hence it can be concluded that the GFC did contribute to growth volatility by somehow interacting with the DRATING variable. The estimated coefficients on the control variables $O I L$ becomes insignificant while that on STOCK becomes significant. The p-value Saragan test statistic imply that the exogeneity condition of the non-included instruments have been met.

The estimation of the model controlling for country specific heterogeneity implies that that there is no time effect. It is possible that some countries in the sample have fixed country effects while others have fixed time effects. This requires the use of the random effect estimator. We employ the generalized two-stage least squares (G2SLS) procedure suggested by Balestra and Varadharajan-Krishnakumar (1987) to account for potential endogeneity and random effects. In addition the expected bias due to the existence of heteroscdasticity in the error term in the data is also corrected for using the method of error corrected generalised two-stage least squares (EC2SLS) estimator as suggested by Baltagi (1995). Columns (2) and (3) of Table 2 presents the generalised 2SLS (G2SLS) and error corrected generalised 2SLS (EC2SLS) estimations. In column (2) the results of the G2SLS estimation are presented. Note that these results are very similar to those in column (1). The coefficients of RATING and DRATING are 
negative and significant at 5 percent level, as well as the estimated coefficient on the interaction term $\left(G F C^{*} D R A T I N G\right)$. The joint test on the coefficients on both DRATING is comfortably

\begin{tabular}{|c|c|c|c|}
\hline \multicolumn{4}{|c|}{$\begin{array}{l}\text { Dependent variable: Volatility of per capita GDP growth } \\
\text { (Instrumental Variable Estimator) } \\
\text { Endogenous variable: RATING }\end{array}$} \\
\hline Regressor & $\begin{array}{c}(1) \\
\text { FE-IV }\end{array}$ & $\begin{array}{c}(2) \\
\text { RE-G2SLS }\end{array}$ & $\begin{array}{c}(2) \\
\text { RE-EC2SLS }\end{array}$ \\
\hline RATING & $\begin{array}{l}-0.000012 \\
(-2.12)^{* *}\end{array}$ & $\begin{array}{l}-0.000011 \\
(-3.97) * * *\end{array}$ & $\begin{array}{l}-0.000012 \\
(-3.06) * * *\end{array}$ \\
\hline DRATING & $\begin{array}{l}-0.000084 \\
(-2.07)^{* *}\end{array}$ & $\begin{array}{l}-0.000041 \\
(-2.76)^{* *}\end{array}$ & $\begin{array}{l}-0.000081 \\
(-1.99)^{* *}\end{array}$ \\
\hline$G F C$ & $\begin{array}{c}0.000013 \\
(0.46)\end{array}$ & $\begin{array}{l}7.2 \mathrm{e}-06 \\
(0.46)\end{array}$ & $\begin{array}{l}7.59 \mathrm{e}-06 \\
(0.77)\end{array}$ \\
\hline$G F C^{*} D R A T I N G$ & $\begin{array}{l}-0.00015 \\
(-2.03)^{* *}\end{array}$ & $\begin{array}{l}-0.00016 \\
(-2.09)^{* *}\end{array}$ & $\begin{array}{l}-0.00016 \\
(-3.10)^{* *}\end{array}$ \\
\hline OIL & $\begin{array}{c}1.83 \mathrm{e}-06 \\
(1.52)\end{array}$ & $\begin{array}{c}1.83 \mathrm{e}-06 \\
(2.57)\end{array}$ & $\begin{array}{c}1.82 \mathrm{e}-06 \\
(1.51)\end{array}$ \\
\hline STOCK & $\begin{array}{l}5.28 \mathrm{e}-16 \\
(1.95)^{*}\end{array}$ & $\begin{array}{l}1.03 \mathrm{e}-16 \\
(0.65)\end{array}$ & $\begin{array}{l}1.25 \mathrm{e}-16 \\
(0.76)\end{array}$ \\
\hline Constant & & $\begin{array}{c}0.00029 \\
(7.07)^{* * *}\end{array}$ & $\begin{array}{c}0.00031 \\
(5.68)^{* * *}\end{array}$ \\
\hline \multicolumn{4}{|l|}{$\begin{array}{l}\chi^{2} \text {-Statistics and } \\
\text { Summary Statistics }\end{array}$} \\
\hline $\begin{array}{l}\chi^{2} \text {-statistic testing } \\
\text { coefficients on } \\
\text { DRATING } \\
\text { (P-value) }\end{array}$ & $\begin{array}{c}13.82 \\
(0.000)\end{array}$ & $\begin{array}{c}14.14 \\
(0.000)\end{array}$ & $\begin{array}{c}14.07 \\
(0.000)\end{array}$ \\
\hline $\begin{array}{l}\text { Number of excluded } \\
\text { instruments }\end{array}$ & $\begin{array}{c}\text { 2: (COMPRISK, } \\
\text { RRET })\end{array}$ & $\begin{array}{c}\text { 2: (COMPRISK, } \\
\text { RRET })\end{array}$ & $\begin{array}{c}\text { 2: (COMPRISK, } \\
\text { RRET) }\end{array}$ \\
\hline $\begin{array}{l}\text { Sargan-statistic for } \\
\text { overidentification of all } \\
\text { instruments (P-value) }\end{array}$ & $\begin{array}{c}0.131 \\
(0.716)\end{array}$ & $\begin{array}{c}0.316 \\
(0.573)\end{array}$ & $\begin{array}{c}0.316 \\
(0.573)\end{array}$ \\
\hline $\mathrm{R}^{2}$ (within) & 0.0044 & 0.0044 & 0.0044 \\
\hline $\begin{array}{l}\text { Wald }-\chi^{2} \\
\text { (P-value) }\end{array}$ & $\begin{array}{l}300.00 \\
(0.000) \\
\end{array}$ & $\begin{array}{l}45.68 \\
(0.000) \\
\end{array}$ & $\begin{array}{c}44.41 \\
(0.000) \\
\end{array}$ \\
\hline $\begin{array}{l}\text { No. of } \\
\text { observation/countries }\end{array}$ & $9809 / 76$ & $9809 / 76$ & $9809 / 76$ \\
\hline
\end{tabular}


rejected. The exogeneity of the instruments is also confirmed via the Sargan test. It is now therefore possible to conclude that the $G F C$ has affected growth volatility by interacting with sovereign rating changes.

In column (2) the variance of the error term is assumed to be homoscedastic. However, we relax this assumption in column (3) in which equation (2) is estimated using the EC2SLS estimator where the variance of the error term is allowed to vary across countries. Having correcting for both endogeneity and heteroscedasticity enable us to obtain more robust results. It can be seen that the results in column (3) are quite similar to those obtained in column (2) and that the link between sovereign credit rating variables and output volatility therefore remains negative and significant. Furthermore, the estimated coefficient of the interaction term is also significant. Therefore it can be concluded that the volatility dampening effects of sovereign credit ratings is robust to alternative estimators and also that the $G F C$ has contributed to the volatility of output growth by weakening this relationship.

In estimating equations (1) and (2), the dependent variable was the volatility of per capita GDP growth which is calculated as the squared deviation of actual growth from the mean. This is an overall measure of output variability. Perhaps even more important are the economic downturns that occur periodically and have long characterised market economies. To analyse the link between rating and economic downturn, a limited dependent variable analysis is performed on the same data. The estimated model is as follows:

$$
\begin{aligned}
& D_{\text {OWN }}=\beta_{0}+\beta_{1} \text { RATING }_{i t}+\beta_{2} \text { DRATING }_{i t}+\beta_{3} G F C_{t}+ \\
& \beta_{4}(G F C \times D R A T I N G)_{i t}+\beta_{6} X_{i t}+u_{i t}
\end{aligned}
$$


The right hand side variables are the same as before but the dependent variable $D O W N$ has been transformed into a binary variable which takes a value equal to 1 when per capita GDP growth is negative or 0 when growth is positive. This allows us to analyse if credit ratings has any implications for negative growth only. We estimate equation (3) using both PROBIT and LOGIT models and choose the best performing model using information criteria such as AIC and BIC.

\section{Table 3}

Dependent variable: Binary variable when per capita GDP growth is negative, dependent variable $=1$; otherwise 0 )

\begin{tabular}{|c|c|c|c|}
\hline Regressor & $\begin{array}{c}(1) \\
\text { PROBIT-RE }\end{array}$ & $\begin{array}{c}(2) \\
\text { LOGIT-RE }\end{array}$ & $\begin{array}{c}(3) \\
\text { PROBIT-IV } \\
\text { (Endogenous } \\
\text { regressor = } \\
\text { RATING) }\end{array}$ \\
\hline RATING & $\begin{array}{l}-0.014 \\
(-1.70)^{*}\end{array}$ & $\begin{array}{c}-0.038 \\
(-1.72)^{*}\end{array}$ & $\begin{array}{c}-0.113 \\
(-1.82)^{*}\end{array}$ \\
\hline DRATING & $\begin{array}{l}-0.101 \\
(-1.33) \\
\end{array}$ & $\begin{array}{l}-0.211 \\
(-1.32)\end{array}$ & $\begin{array}{l}-0.048 \\
(-0.50)\end{array}$ \\
\hline$G F C$ & $\begin{array}{l}-0.121 \\
(-1.22)\end{array}$ & $\begin{array}{l}-0.320 \\
(-1.18)\end{array}$ & $\begin{array}{l}-0.076 \\
(-0.59)\end{array}$ \\
\hline$G F C^{*} D R A T I N G$ & $\begin{array}{l}0.016 \\
(0.09)\end{array}$ & $\begin{array}{l}0.027 \\
(0.06)\end{array}$ & $\begin{array}{l}0.023 \\
(0.12)\end{array}$ \\
\hline OIL & $\begin{array}{l}0.003 \\
(0.84)\end{array}$ & $\begin{array}{l}0.010 \\
(0.85)\end{array}$ & $\begin{array}{c}-0.003 \\
(-0.057)\end{array}$ \\
\hline STOCK & $\begin{array}{c}3.17 \mathrm{e}-13 \\
(0.60)\end{array}$ & $\begin{array}{c}8.06 \mathrm{e}-13 \\
(0.59)\end{array}$ & $\begin{array}{c}-2.67 \mathrm{e}-11 \\
(-1.72)^{*}\end{array}$ \\
\hline Constant & $\begin{array}{c}-2.182 \\
(-17.41)^{* * *}\end{array}$ & $\begin{array}{c}-4.215 \\
(-12.75)^{* * *}\end{array}$ & $\begin{array}{c}-1.165 \\
(109.93)^{* * *}\end{array}$ \\
\hline \multicolumn{4}{|l|}{ Summary Statistics } \\
\hline Log likelihood & -551.771 & -552.004 & -11751.216 \\
\hline AIC & 1117.543 & 1118.01 & \\
\hline $\mathrm{BIC}$ & 1168.429 & 1168.896 & \\
\hline $\begin{array}{l}\text { Wald test of exogeneity } \\
\text { (p-value) }\end{array}$ & & & 0.185 \\
\hline $\begin{array}{l}\text { No. of } \\
\text { observation/countries }\end{array}$ & $9809 / 76$ & $9809 / 76$ & $9809 / 76$ \\
\hline
\end{tabular}


The results are summarised in Table (3), where column (1) represents the PROBIT random effect estimation of equation (3) and column (2) represents the LOGIT random effect estimations. The results are very similar across these two estimators, but in terms of the information criteria as given by AIC and BIC, it seems the PROBIT is the best performing model. However, it can be seen that in both estimations the coefficient on RATING is negative and significant at the 10 percent level of significance. So there is some evidence, albeit very weak, that credit ratings also lead to a reduction in economic downturn.

Estimating only a PROBIT random effect model leaves open the possibility that the variable RATING could be endogenous, generating a bias in the estimate reported in column (1). This problem is further investigated by estimating equation (3) with probit instrumental variable (PROBIT-IV) estimator where the endogenous regressor is RATING. The results are reported in column (3) where we can still find the coefficient of RATING negative and significant at 10 percent level. We have used COMPRISK and RRET as instruments and the Wald test do not reject the null of exogeneity of instruments. 
The final model presented in this paper to analyse the sovereign credit rating - output volatility link is based on the simultaneous interaction between these two variables - just as sovereign credit ratings can affect output volatility; it can also be affected by output volatility. A simultaneous relationship between sovereign ratings and output volatility requires an appropriate model and estimator that can account for this joint determination of ratings and output volatility. With these objectives the following model is estimated:

$$
\begin{aligned}
& V O L_{i t}=\beta_{0}+\beta_{1} R_{A T I N G}+\beta_{2} D_{i t} A T I N G_{i t}+\beta_{3} G F C_{t}+ \\
& \beta_{4}(G F C \times D R A T I N G)_{i t}+\beta_{6} X_{i t}+u_{i t} \\
& R A T I N G_{i t}=\delta_{0}+\delta_{1} V O L_{i t}+\delta_{2} M O N E Y+\delta_{3} I N F+\delta_{4} C O M P R I S K+ \\
& \delta_{5} L G D P+\delta_{6} G R O W T H+\delta_{7} V I N F+\varepsilon_{i t}
\end{aligned}
$$

The variables in equation (4.1) are the same as before and some of the variables in equation (4.2) are potential determinants of sovereign credit ratings. MONEY is monetary policy stance, INF is the rate of inflation, COMPRISK is composite risk as measured by ICRG, LGDP stands for the log of GDP, GROWTH is per capita GDP growth, and VINF is the volatility of inflation. To explain sovereign credit ratings, our choice of control variables has been guided by the literature on the fundamental economic determinants of country risk and sovereign default risk (Cantor and Packer, 1996, Hilscher and Nosbusch, 2010) indicating that macroeconomic variables like inflation (INF, VINF), GDP (LGDP and GROWTH), interest rates (MONEY) are important determinants as deteriorations in a country's macroeconomic conditions will severely affect the government's ability to repay its debts. We also include a composite risk measure (COMPRISK) sourced from the International Country Risk Guide (ICRG) as it 
incorporates aspects of financial, economic and political risks within countries and has been documented to be important for growth opportunities by Bekaert et al. (2007).

Equations (4.1) and (4.2) are jointly estimated as a system using the three stage least square estimator and the results are presented in Table 4. Column (1) presents the estimated coefficients of the volatility equation. It can be seen that the signs of the estimated coefficients and their significance are very similar to those in Table 3. In particular, the estimated coefficient of RATING and DRATIING are negative and significant as before confirming the notion that improvements in sovereign credit quality can reduce growth volatility. What can also be seen from the volatility equation in Table 4 is that the estimated coefficient on the interaction term $\left(G F C^{*} D R A T I N G\right)$ is negative and significant. The joint test on the coefficients of DRATING clearly rejects the null hypothesis. This leads to the conclusion that whilst the direct effect of the GFC on growth volatility has been insignificant, the indirect effect of the $G F C$ has been its contribution in weakening the volatility reducing effect of sovereign credit quality. Among the control variables, oil prices $(O I L)$ have consistently contributed towards higher output volatility as evidenced by the positive and significant coefficients in all model specifications. It might be worth mentioning that the $\mathrm{R}^{2}$ is quite low for the equation 4.1 , which could be because of a poor fit of the model due to unavailability of more suitable control variables. However, this is not entirely unexpected as the literature on the determinants of growth volatility has yet not become enough mature to suggest the range of control variables that might be important.

In column (2) the estimated coefficients of the RATING equation is presented. It can be seen that volatility itself is a major determinant of sovereign credit ratings because the estimated sign of $V O L$ is negative and significant. This implies that increase in GDP volatility will lead 
to lower ratings. With regard to the policy variables MONEY, INF and VINF seem to be important as these are instruments for conducting monetary policy. The variable MONEY which is an indicator variable set equal to one if the short-term interest rate was increased (until the next interest rate cut), and zero otherwise represents the monetary policy stance of the authority. With a positive and significant estimated coefficient on this variable it can be concluded that a tightening in monetary policy can increase sovereign credit ratings because it shows the commitment of the monetary authority to discipline the economy. On the contrary high inflation and inflation volatility can lead to lower sovereign ratings as the estimated coefficients on $I N F$ and VINF are negative and significant at the 1 percent level. High inflation and high volatility of inflation represents an unstable macroeconomic environment which leads to a decline in sovereign credit quality. 
Table 4

Dependent variables: Volatility of per capita GDP growth, Sovereign Credit Ratings (Three stage least squares (3SLS) estimator)

Endogenous Variables: Volatility of per capita GDP growth, Sovereign Credit Ratings

\begin{tabular}{|c|c|c|}
\hline Regressor & $\begin{array}{c}(1) \\
\text { VOLATILITY }\end{array}$ & $\begin{array}{c}(2) \\
\text { RATING }\end{array}$ \\
\hline RATING & $\begin{array}{l}-0.000015 \\
(-6.47) * * *\end{array}$ & \\
\hline DRATING & $\begin{array}{l}-0.000105 \\
(-2.65)^{* * *}\end{array}$ & \\
\hline$G F C$ & $\begin{array}{c}9.50 \mathrm{e}-06 \\
(0.41)\end{array}$ & \\
\hline$G F C * D R A T I N G$ & $\begin{array}{l}-0.000126 \\
(-1.69)^{*}\end{array}$ & \\
\hline OIL & $\begin{array}{l}2.76 \mathrm{e}-06 \\
(2.46) * *\end{array}$ & \\
\hline STOCK & $\begin{array}{c}2.10 \mathrm{e}-17 \\
(0.884)\end{array}$ & \\
\hline VOL & & $\begin{array}{c}-11.6914 \\
(-4.02)^{* * *}\end{array}$ \\
\hline MONEY & & $\begin{array}{c}0.36735 \\
(8.02)^{* * *}\end{array}$ \\
\hline$I N F$ & & $\begin{array}{c}-0.22152 \\
(-6.59) * * *\end{array}$ \\
\hline COMPRISK & & $\begin{array}{c}0.33421 \\
(73.37)^{* * *}\end{array}$ \\
\hline$L G D P$ & & $\begin{array}{c}1.43645 \\
(51.11)^{* * *}\end{array}$ \\
\hline GROWTH & & $\begin{array}{c}0.05054 \\
(0.02)\end{array}$ \\
\hline VINF & & $\begin{array}{c}-0.17487 \\
(-7.47)^{* * *}\end{array}$ \\
\hline CONS & $\begin{array}{l}0.000356 \\
(10.82) * * *\end{array}$ & $\begin{array}{c}-20.8765 \\
(82.71)^{* * *}\end{array}$ \\
\hline $\begin{array}{l}\chi^{2} \text {-Statistics and Summary } \\
\text { Statistics }\end{array}$ & & \\
\hline $\begin{array}{l}\chi^{2} \text {-statistic testing } \\
\text { coefficients on DRATING } \\
\text { (P-value) }\end{array}$ & $\begin{array}{c}9.16 \\
(0.002)\end{array}$ & \\
\hline $\mathrm{R}^{2}$ & 0.0075 & 0.8269 \\
\hline RMSE & 0.0009 & 2.0859 \\
\hline $\begin{array}{l}\text { Identification: (Equation } 4.1 \\
\& 4.2 \text { ) }\end{array}$ & Identified & Identified \\
\hline Identification of System & \multicolumn{2}{|c|}{ Identified } \\
\hline $\begin{array}{l}\chi^{2} \text {-statistic (overall) } \\
(\mathrm{P}-\text {-value })\end{array}$ & $\begin{array}{l}71.38 \\
(0.000)\end{array}$ & $\begin{array}{c}42420.35 \\
(0.000)\end{array}$ \\
\hline No. of observation/countries & $8873 / 76$ & $8873 / 76$ \\
\hline
\end{tabular}


Note: For variable definitions of column (1) please see notes under Table 1. $V O L=$ volatility of the growth of per capita real GDP; MONEY = monetary policy stance; $I N F=$ the rate of inflation; COMPRISK = composite risk as measured by ICRG; $L G D P=\log$ of GDP; GROWTH = per capita GDP growth, and VINF = volatility of inflation. * $\mathrm{p}<0.1 ; * *$ $\mathrm{p}<0.05 ; * * * \mathrm{p}<0.01$

The crucial aspect of the system of equations estimated in Table 4 is identification of the structural parameters. The usual order condition relating to single equation IV estimation is satisfied by counting the included endogenous variables and non-included exogenous variables and the sufficient rank condition pertains to the rank of the matrix of instruments. For a system of equations like 4.1 and 4.2 , in the 3 SLS estimation context it could be possible that each equation is individually identified yet the system is unidentified. In this context of identification what is referred is the unique relationship between the matrices of structural coefficients and the reduced form of the linear system. For the system is to be identified, unique values of the structural coefficients from those of the reduced form must be derived (Wooldridge, 2002, p. 218). We perform a check on the condition for identification of our structural system and find that it is satisfied for each equation individually and also for the system as a whole. The results are reported in Appendix I.

Another issue with the estimation of the system of equations like 4.1 and 4.2 is that, although 3SLS estimator explicitly takes simultaneity into account as well as the cross-equation error correlations to improve large sample efficiency, it imposes the assumption of homoscedasticity on the error term (Wooldridge. 2002). Hayashi (2000) shows 3SLS estimator is a special case of multiple equation GMM estimator, and with non-i.i.d. errors Optimal System GMM estimator produce consistent and efficient estimates. Therefore as a final robustness check we estimate the system of equations in (4.1) and (4.2) using multiple equation GMM estimator with heteroschedasticity-consistent standard errors and the results are presented in Table A1 in Appendix II. Although there are some changes compared to what is found in Table 4, the results 
with the GMM estimates are on average comparable to those with 3SLS. The most fundamental result with regard to the central hypothesis of this paper remains unaltered. This is confirmed by looking at the signs of the estimated coefficients of DRATING and the interaction term between $G F C$ and DRATING, both of which are negative and significant at 1 percent. As mentioned earlier in this section, the coefficient of change in sovereign credit rating (DRATING), i.e. $\beta_{2}$ is more important because the volatility of $G D P$ should be more reactive to changes in the informational content of the economy which is more appropriately conveyed by ratings changes. The estimated negative sign of interaction term implies GFC has weakened volatility reducing effect of rating changes.

\section{Sovereign Credit Spreads and Ratings}

In the preceding sections an attempt has been made to empirically establish a link between sovereign credit ratings and growth volatility. The evidence confirms that such a relationship exists and that it is robust and unambiguous. In this section we make an attempt to explain why improvements in a country's sovereign credit assessment will reduce output volatility . The mechanism by which sovereign credit ratings and changes in ratings affect growth volatility can be attributed to the relationship between ratings and the sovereign credit default swap (CDS) spread. That is sovereign credit rating changes may cause higher volatility in the sovereign CDS spreads exacerbating the uncertainty of the market's perception on whether a sovereign is going to default and this has real economic consequences and can affect output volatility. 


\begin{tabular}{|c|c|c|c|c|}
\hline & Rating Char & $\begin{array}{r}\text { Table } \\
\text { Sovereign }\end{array}$ & ead and vol & \\
\hline Variables & & & Variables & \\
\hline & & pread & & latility \\
\hline RATINGS & $\begin{array}{l}-0.00329 \\
(-3.23) * * *\end{array}$ & $\begin{array}{l}-0.00323 \\
(-3.27)^{* * *}\end{array}$ & $\begin{array}{l}-0.00053 \\
(-2.82) * * *\end{array}$ & $\begin{array}{l}-0.00054 \\
(-2.80)^{* * *}\end{array}$ \\
\hline DRATING & $\begin{array}{l}-0.01219 \\
(-2.13)^{* *}\end{array}$ & & $\begin{array}{l}-0.00383 \\
(-2.08)^{* *}\end{array}$ & \\
\hline $\begin{array}{l}\text { POSITIVE } \\
\text { DRATING }\end{array}$ & & $\begin{array}{l}-0.00275 \\
(-0.62)\end{array}$ & & $\begin{array}{l}-0.00228 \\
(-0.68)\end{array}$ \\
\hline $\begin{array}{l}\text { NEGATIVE } \\
\text { DRATING }\end{array}$ & & $\begin{array}{l}0.05657 \\
(2.86)^{* * * *}\end{array}$ & & $\begin{array}{l}0.01181 \\
(2.41)^{* *}\end{array}$ \\
\hline OIL & $\begin{array}{l}-0.00033 \\
(-2.63) * * *\end{array}$ & $\begin{array}{l}-0.00032 \\
(-2.60)^{* * * *}\end{array}$ & $\begin{array}{l}-0.00015 \\
(-7.90) * * *\end{array}$ & $\begin{array}{l}-0.00015 \\
(-7.85)^{* * * *}\end{array}$ \\
\hline GROWTH & $\begin{array}{l}-0.22144 \\
(-3.55)^{* * *}\end{array}$ & $\begin{array}{l}-0.21677 \\
(-3.45)^{* * *}\end{array}$ & $\begin{array}{l}-0.08027 \\
(-2.22)^{* *}\end{array}$ & $\begin{array}{l}-0.07826 \\
(-2.17)^{* *}\end{array}$ \\
\hline$I N F$ & $\begin{array}{l}0.05427 \\
(2.17) * *\end{array}$ & $\begin{array}{l}0.52667 \\
(2.10) * *\end{array}$ & $\begin{array}{l}0.02765 \\
(15.73)^{* * * *}\end{array}$ & $\begin{array}{l}0.02744 \\
(15.55)\end{array}$ \\
\hline CONS & $\begin{array}{l}0.05808 \\
(4.00)^{* * *}\end{array}$ & $\begin{array}{l}0.05659 \\
(4.05)^{* * *}\end{array}$ & $\begin{array}{l}0.00741 \\
(2.38)^{* *}\end{array}$ & $\begin{array}{l}0.00731 \\
(2.34)^{* *}\end{array}$ \\
\hline $\begin{array}{l}\text { NO. OF } \\
\text { OBS/GROUPS }\end{array}$ & $4530 / 70$ & $4530 / 70$ & $4530 / 70$ & $4530 / 70$ \\
\hline WALD $\chi^{2}$-statistic & $\begin{array}{l}19.73 \\
(0.001)\end{array}$ & $\begin{array}{l}8.99 \\
(0.109)\end{array}$ & $\begin{array}{l}29.52 \\
(0.000)\end{array}$ & $\begin{array}{l}12.55 \\
(0.050)\end{array}$ \\
\hline WITHN $R^{2}$ & 0.266 & 0.105 & 0.276 & 0.106 \\
\hline
\end{tabular}

In Table 5 we report generalised least squares (GLS) estimates on the effects of sovereign credit rating changes on both CDS spread and CDS spread volatility. The volatility of sovereign CDS spreads (CDS Volatility $_{i, t}$ ) is computed as the arithmetic averages of the square of daily CDS spread changes within calendar months. The estimations control for unobserved effects using random effect (RE) models with clustered error which gives within group heteroscedasticity and autocorrelation robust standard errors. Our variable of interest is DRATING. We also create a new variable POSITIVE DRATING which is an indicator variable taking a value equal to 1 when DRATING is non-zero and positive and zero otherwise. Similarly, NEGATIVE DRATING is equal to 1 when a rating change is negative. We have also used world oil price, GDP growth per capita and inflation rate as control 
variables for determining sovereign CDS spreads and its volatility as Ismailescu and Kazemi (2010) have shown that these two measures of sovereign credit risk closely track each other. The findings show that credit rating changes have a negative impact on CDS spread and on its volatility. This can be seen from the coefficient on DRATING which is negative and significant. However what is interesting to note is that this effect is asymmetric. The effect of positive changes in sovereign credit ratings is negative but insignificant. However, the effect of negative rating changes is positive and significant for both sovereign CDS spread and its volatility. However, since on the aggregate DRATING lowers sovereign CDS spread and CDS spread volatility, sovereign credit rating changes can help reduce uncertainty in the overall macroeconomy and thus lead to lower output volatility.

\section{Conclusions}

The empirical fact that output volatility may induce lower growth (Ramey and Ramey, 1995) is an important finding for policy makers because reducing growth volatility can be a means to achieving higher economic growth. Hence, in this study we investigate the relationship between sovereign credit ratings and output volatility. Using monthly data from January 1996 to May 2010 for a panel of 76 developed and emerging economies and adopting an instrumental variable estimation technique by correcting for both heterogeneity and endogeneity using the generalized two-stage least squares (G2SLS, EC2SLS) procedure method suggested by Balestra and Varadharajan-Krishnakumar (1987) and Baltagi (1995), this paper provides empirical evidence that an alternative channel via which growth volatility is reduced is through improvements in sovereign credit ratings. The paper also provides a new insight on the effect of the Global Financial Crisis (GFC). We reveal that the GFC contributed towards increased macroeconomic volatility by weakening the volatility dampening effect of sovereign credit ratings. Acknowledging the simultaneity between sovereign ratings and 
growth volatility, the paper adopts a system approach and uses a three stage least squares (3SLS) estimator to ascertain that the volatility reducing effect of sovereign ratings is robust. The 3SLS estimates also show that monetary policy stance, inflation and inflation volatility are major determinants of sovereign ratings. Hence, monetary policy can be effectively used to increase a country's sovereign credit rating and to achieve lower output volatility. Lastly, we find that changes in sovereign credit ratings lowers sovereign credit spreads and spread volatility and we postulate this reduces economic uncertainty and in turn leads to lower output volatility in the real economy. 


\section{Data Appendix}

\begin{tabular}{|c|c|c|}
\hline Variable & Data Definition & Sources \\
\hline VOL & $\begin{array}{l}\text { Volatility of per capita GDP } \\
\text { growth measured as squared } \\
\text { deviation of per capita GDP } \\
\text { growth from its trend. }\end{array}$ & $\begin{array}{l}\text { Calculated by author. } \\
\text { Data from Datastream. }\end{array}$ \\
\hline RATING & $\begin{array}{l}\text { Sovereign credit ratings } \\
\text { provided by Standard and } \\
\text { Poors. The ratings have been } \\
\text { converted to a linear time } \\
\text { series following Gande and } \\
\text { Parsley (2005). }\end{array}$ & Standard and Poors. \\
\hline DRATING & First difference on RATING & Calculated by author. \\
\hline$G F C$ & $\begin{array}{l}\text { Binary variable }=1 \text { if time } \\
\text { equals 2010:07 to 2010:05. It } \\
\text { represents the period during } \\
\text { the Global Financial Crisis. }\end{array}$ & Calculated by author. \\
\hline OIL & World oil price & Datastream. \\
\hline STOCK & $\begin{array}{l}\text { Total value of shares traded } \\
\text { during the period (current } \\
\text { US\$). }\end{array}$ & Datastream. \\
\hline MONEY & $\begin{array}{l}\text { An indicator variable set } \\
\text { equal to one if the short-term } \\
\text { interest rate was increased } \\
\text { (until the next interest rate } \\
\text { cut), zero otherwise. }\end{array}$ & Datastream. \\
\hline INF & Inflation rate. & Datastream. \\
\hline VINF & $\begin{array}{l}\text { Volatility of inflation rate } \\
\text { measured as the deviation of } \\
\text { actual inflation from its mean. }\end{array}$ & Calculated by author. \\
\hline$L G D P$ & $\begin{array}{l}\text { Log of Gross domestic } \\
\text { product - value of goods } \\
\text { produced per person in the } \\
\text { country. }\end{array}$ & Datastream. \\
\hline GROWTH & $\begin{array}{l}\text { Real GDP per capita growth } \\
\text { rate. }\end{array}$ & Datastream. \\
\hline COMPRISK & Composite risk measure. & $\begin{array}{l}\text { International Country Risk } \\
\text { Guide (ICRG) }\end{array}$ \\
\hline RRET & Realised equity market return & $\begin{array}{l}\text { Calculated by the author } \\
\text { from S\&P500 index. Data } \\
\text { from Datastream. }\end{array}$ \\
\hline
\end{tabular}




\section{Appendix I - Identification test of system of equations 4.1 and 4.2}

\begin{tabular}{|l|l|l|}
\hline Endogenous Coefficient Matrix & \\
\hline & VOL & RATING \\
\hline VOL & -1 & 0.5 \\
\hline RATING & 0 & -1 \\
\hline
\end{tabular}

\begin{tabular}{|l|l|l|l|l|l|l|}
\hline \multicolumn{6}{|l|}{ Exogenous Coefficient Matrix } \\
\hline & RATING & DRATING & GFC & GFC*DRATING & OIL & STOCK \\
\hline VOL & 0.5 & 0.5 & 0.5 & 0.5 & 0.5 & 0.5 \\
\hline RATING & 0 & 0 & 0 & 0 & 0 & 0 \\
\hline
\end{tabular}

\begin{tabular}{|l|l|l|l|l|l|l|l|}
\hline \multicolumn{2}{|l|}{ Exogenous Coefficient Matrix } \\
\hline & VOL & MONEY & INFLATION & COMPRISK & LGDP & GROWTH & VINF \\
\hline VOL & 0 & 0 & 0 & 0 & 0 & 0 & 0 \\
\hline RATING & 0.5 & 0.5 & 0.5 & 0.5 & 0.5 & 0.5 & 0.5 \\
\hline
\end{tabular}

Note: Eq. $4.1 \& 4.2$ individually identified and the system is identified. These results based on Stata procedure "checkreg3" 3 which allows to see that the necessary and sufficient rank condition is satisfied for each of the $\mathrm{N}$ equations in the system unless which the system is unidentified. The values 0.5 are used only as placeholders to check identification status.

\footnotetext{
${ }^{3}$ Baum, C.F., (2007) checkreg3: Stata module to check identification status of simultaneous equations system. http://ideas.repec.org/c/boc/bocode/s456877.html
} 


\section{Appendix II - System GMM estimation of equations 4.1 and 4.2}

\section{Table A1}

Dependent variables: Volatility of per capita GDP growth, Sovereign Credit Ratings (System GMM)

Endogenous Variables: Volatility of per capita GDP growth, Sovereign Credit Ratings

\begin{tabular}{|c|c|c|}
\hline Regressor & $\begin{array}{c}(1) \\
\text { VOLATILITY }\end{array}$ & $\begin{array}{c}(2) \\
\text { RATING }\end{array}$ \\
\hline RATING & $\begin{array}{c}0.000051 \\
(5.10)^{* * *}\end{array}$ & \\
\hline DRATING & $\begin{array}{l}-0.003447 \\
(-2.57) * * *\end{array}$ & \\
\hline$\overline{G F C}$ & $\begin{array}{l}-0.000757 \\
(-2.13)^{* *}\end{array}$ & \\
\hline$G F C * D R A T I N G$ & $\begin{array}{c}-0.094474 \\
(-26.34) * * *\end{array}$ & \\
\hline OIL & $\begin{array}{c}0.000046 \\
(13.02)^{* * *}\end{array}$ & \\
\hline STOCK & $\begin{array}{l}-1.47 \mathrm{e}-14 \\
(-5.96) * * *\end{array}$ & \\
\hline VOL & & $\begin{array}{c}-29.4800 \\
(-1.36) \\
\end{array}$ \\
\hline MONEY & & $\begin{array}{c}-4.7099 \\
(-1.58)\end{array}$ \\
\hline$I N F$ & & $\begin{array}{c}-2.1958 \\
(-9.88)^{* * *}\end{array}$ \\
\hline COMPRISK & & $\begin{array}{c}0.04622 \\
(1.84)^{*}\end{array}$ \\
\hline$L G D P$ & & $\begin{array}{c}2.3124 \\
(11.73)^{* * *}\end{array}$ \\
\hline GDP GROWTH & & $\begin{array}{c}-2.3711 \\
(-0.12) \\
\end{array}$ \\
\hline VINF & & $\begin{array}{c}0.20074 \\
(1.25)\end{array}$ \\
\hline No. of observation/countries & $6518 / 76$ & $6518 / 76$ \\
\hline
\end{tabular}




\section{References:}

Baltagi, B. H. 2008. Econometric Analysis of Panel Data. 4th ed. New York: Wiley.

Balestra, P., and J. Varadharajan-Krishnakumar. 1987. Full information estimations of a system of simultaneous equations with error component structure. Econometric Theory 3: 223246.

Bekaert, G., C. R. Harvey, C. Lundblad, and S. Siegel, 2007, Growth Opportunities and Market Integration, Journal of Finance 62, 1081-1137.

Bernanke, B. S. 1983. "Irreversibility, Uncertainty, and Cyclical Investment." Quarterly Journal of Economics 98:85-106.

Brooks, R., Faff, R., Hillier, D., Hillier, J., 2004. "The national market impact of sovereign rating changes." Journal of Banking and Finance 28, 233-250.

Black, F. 1987. Business Cycles and Equilibrium. Cambridge, MA: Blackwell.

Cantor, R., and F. Packer, 1996, Determinants and Impact of Sovereign Credit Ratings, Federal Reserve Bank of New York Economic Policy Review 2, 37-53.

Cavallo E., A. Powell and R. Rigobon. 2008. "Do Credit Rating Agencies Add Value? Evidence from the Sovereign Rating Business Institutions", Inter-American Development Bank, Working Paper No.647, Washington, DC.

Darby, M.R., 1982, The price of oil and world inflation and recession, American Economic Review 72, 738-751.

Easterly, W., R. Islam, and J. Stiglitz. 2001. "Shaken and Stirred: Explaining Growth Volatility," Annual World Bank Conference on Development Economics, B. Pleskovic and N. Stern (eds.), Washington D.C.: World Bank.

Gaillard, N. 2009. 'Fitch, Moody's and S\&P's Sovereign Ratings and EMBI Global Spreads: Lessons from 1993-2007”, International Research Journal of Finance and Economics, April.

Gande, A., Parsley, D.C., 2005. "News spillovers in the sovereign debt market." Journal of Financial Economics, 75: 691-734.

Hayashi, F. 2000. Econometrics, NJ: Princeton University Press

Hilscher, J. and Y. Nosbusch 2010. Determinants of sovereign risk: macroeconomic fundamentals and the price of sovereign debt, Review of Finance 14, 235-262. 
Ismailescu, I., H. Kazemi, 2010. The reaction of emerging market credit default swap spreads to sovereign credit rating changes, Journal of Banking and Finance 34, 2861-2873

Kaminsky, G. and S. Schmuukler. 2001. "Emerging Markets Instability: Do Sovereign Ratings Affect Country Risk and Stock Returns?”, World Bank Working Paper 2678, Washington, DC.

Kim, S-J. and E. Wu. 2008. "Sovereign credit ratings, capital flows and financial sector development in emerging markets", Emerging Markets Review, 9(1): 17-39.

Kim, S-J. and E. Wu. 2011. "International bank flows to emerging markets: Influence of sovereign credit ratings and their regional spillover effects", Journal of Financial Research, 34(2): 331-365.

Kydland, F. and E. Prescott. 1982. "Time to Build and Aggregate Fluctuations." Econometrica 50: $1345-70$.

Levine, R., and S. Zervos, 1998, Stock markets, banks and economic growth, American Economic Review 88, 537-58.

Mendoza, E., 1997, "Terms of Trade Uncertainty and Economic Growth," Journal of Development Economics 54: 323-356.

Mora, N. 2006. "Sovereign credit ratings: guilty beyond reasonable doubt?", Journal of Banking and Finance 30.

Mathis, J., J McAndrews, and J. C. Rochet. 2009. "Rating the Raters: Are reputation concerns powerful enough to discipline rating agencies", Journal of Monetary Economics 56(5): 657674.

Ozatay, F., Ozmen, E., Sahinbeyoglu, G., 2009. "Emerging market sovereign spreads, global financial conditions and US macroeconomic news," Economic Modelling 26: 526-531.

Pindyck, R. S. 1991. "Irreversibility, Uncertainty, and Investment." Journal of Economic Literature 29:1110-48.

Prasad, E., K. Rogoff, S. Wei, and M. A. Kose. 2004. "Financial Globalization, Growth and Volatility in Developing Countries,” NBER Working Paper 10942.

Ramey, G. and V. A. Ramey. 1995. "Cross-Country Evidence on the Link Between Volatility and Growth." American Economic Review 85:1138 - 1151.

Rao, B. and Hassan, G. 2012. "Are Direct and Indirect Growth Effects of Remittances Significant?" The World Economy 35: 351-372.

Ratha, D., P. De and S. Mohapatra (2011) "Shadow Sovereign Rating for Unrated Developing Countries" World Development, Vol. 39: 295-307. 
Reisen, H., Von Maltzan, 1999. Boom and bust and sovereign ratings. International Finance 2, 273-293.

Roubini, N. and Manasse, P. 2005. "Rules of Thumb" for Sovereign Debt Crises", International Monetary Fund, IMF Working Paper 05/42, Washington, DC.

Sy, A. 2002. "Emerging Market Bond Spreads and Sovereign Credit Ratings: Reconciling Market Views with Economic Fundamentals", Emerging Markets Review 3: 380-408.

Wooldridge, J. 2002. Econometric Analysis of Cross Section and Panel Data, Cambridge, MA: MIT Press 